\title{
Librarians as Cultural Guardians and as Information Professionals
}

\author{
by Rose Simon
}

$T$

here is concern in library circles that despite our role as the "information professionals" in American society - a role we have claimed for well over a century - information vendors have succeeded in establishing for-profit entities that appear to compete with library reference services. "Our own" clients actually pay these entrepreneurs for information that we would provide for free. Worse yet, the transaction sometimes involves the sale of information that was originally given to the vendor by a library.

On a larger scale, the problem is even more serious: parent agencies are hiring groups of "computer people" to manage sizeable information systems without even considering that their own librarians might be the appropriate people to use.

How is it possible that the library profession, after decades of information service to American communities and educational institutions, could find itself so underestimated and overlooked? More importantly, what can be done about it?

Part of the problem is the old "image thing" and the ways in which we perpetuate it. Except for special librarians working for businesses, librarians work in the non-profit sector. Along with teachers and museum curators, librarians serve as the guardians of culture. As in the nineteenth century, we are committed to the notion that literacy and reading lead to enhanced knowledge, the basis of a good quality of life for the individual, and a rich and vital culture for society. We provide information in a variety of formats, and we fiercely protect the rights of access to that information on behalf of our fellow citizens. This is the basis of our professional definition, and it has not changed in over a century. Nor should it. But somehow we have remained Cultural Guardians while the computer people have, in the public view, become the Information Professionals.

Having established ourselves in a time when information transfer took place only through direct speech and the written or printed word, we still retain the trappings of our predecessors in ways that permit the computer people to look new and exciting to information seekers. Look at our library facilities and our job descriptions. Despite the fact that many catalogs are automated and that libraries offer numerous online services, libraries are basically perceived as buildings that house thousands of books, videos, and records and that offer places for learning activities ranging from story hours to simple sitting and reading or writing. Libraries are public buildings associated with books, with learning, and with general social good. Librarians are pleased to be generalists who carry out a wide variety of tasks in a given day. The same librarian who performs a DIALOG search in the morning may teach a BI class or select a number of books for purchase that afternoon. We have different areas of expertise, but few librarians profess to be specialists. Moreover, regardless of the job title, everyone is called a librarian.

Computer people are not encumbered by decades of tradition and thousands of books. Most of their resources are available online and their work place was designed for these specialized functions; they are specialists in a world that believes in the expertise of specialists; and as specialists in an area of intense demand, they command high (certainly better) salaries. If someone wants detailed information from a complex computer search, will he go to the computer person, or to the one who just finished reading Bambi to a group of third graders?

So how do we Cultural Guardians, who believe it is important that society continue to have us, manage also to be recognized as the Information Professionals?

Either kings must become philosophers, or philosophers must become kings. We worry that computer people lack the librarians' professional commitment to information confidentiality and information access for all citizens. But it is likely that solutions to those problems can be found by people other than professional librarians. It seems to me that if librarians believe that it is essential for us to retain our role as the Information Professionals, then we are going to have to learn a great deal more about computers and online systems, and we are going to have to demonstrate that we can deliver the product as effectively as the computer people. That means better and more thorough training, and it means emphasizing on an unprecedented scale how much the library is or can be the "information place." Parent agencies will have to be convinced that the library is where to find the right people for the job.

Librarians who are unwilling to learn the necessary technical skills and who are unable to create a new image of libraries at least as effective as the old one will remain Cultural Guardians, but they will be only that. 


\title{
So, What's Wrong With A Little Culture?
}

\author{
by Harry Tuchmayer, Column Editor
}

\begin{abstract}
$T$
he only crisis I'm aware of is the one in our own minds! We are, as a profession, basically uncomfortable with admitting who we really are. Insecure, and unsure of whether or not we will be respected for what we do, librarians are continually trying to convince each other that what we do really matters anymore. In a society obsessed with labels and buzzwords, I can't help but think that we somehow feel left out of the new lexicon. While garbage collectors have become sanitation engineers, and typists, data entry specialists, librarians can't seem
\end{abstract} to convince anybody that we should be called "information specialists." Yet, the basic fact remains that we do provide people with the information they need and are considered by many to be the best source of information anywhere around.

So what's the big deal? Rose, you defined the problem beautifully when you said, "...the problem is the old image thing," but you've missed the point completely when you continue to insist that we are unwilling to learn the technical skills necessary to create a new image. We don't need to learn new skills (because most of us already have them), and we most certainly don't need a new image (because we have a damned good one). What we really need is assertiveness training! The problem is not in how we perpetuate the image of librarians, but rather that we are ashamed of it! People like, need, and yes, even respect, librarians for what they do; we just can't see it.

Admittedly, we could be better schooled in information retrieval techniques and computer programming, but ask any reference librarian in a public library and they'll tell you how often we are called upon to find critical information for a struggling entrepreneur, produce and retrieve scientific citations for a small manufacturing firm, or even print out the latest demographic data for local government, in between helping a "little old lady" find a less risque romance or discussing the latest Diana biography with a regular patron. We don't need new skills; we just need to be a little bit more confident in our considerable abilities to manage the information explosion.

No doubt, librarians have been largely bypassed by big firms and large businesses whose need for information is so great (or so specialized) that they've created their own departments to handle it. And no doubt we can do better in educating these people about the benefits of hiring librarians to manage their information needs. But what about the vast majority of information seekers, average citizens whose information needs are no less important

\section{Part of the problem is the old "image thing" and the ways in which we perpetuate it.}

- Simon

\section{We have succumbed to the misguided belief that modern is better than traditional .... \\ - Tuchmayer} than business; those who find in the library all the information they need to understand their illnesses, repair their roofs, evaluate their hidden treasures, or find jobs? These are the people we serve, and we serve them well. And you know what? They don't have any problem asking a librarian to help them find the information they need!

Let's stop making excuses for who we are and instead take the iniative in leading the information explosion. We must continue to remind business and government leaders that librarians are the ones who have been organizing, indexing, and disseminating information for decades and are precisely the professionals we want deciding the direction to take for the information future. Just because we aren't paid what we're worth doesn't mean our services aren't valued (and valuable).

The crisis, if there is one, is one largely of our own making. We have succumbed to the misguided belief that modern is better than traditional, and glitzy is better than commonplace. We have somehow come to believe that because we as a profession have not "spiced-up" our image and adopted a new, slick nomenclature, we have lost our competitive edge. This is pure poppycock! We have lost nothing but our own respect. We have successfully moved into the twenty-first century without abandoning our cultural heritage. Rather than vilify, we should applaud a profession that has been able to move ahead without selling out. I for one am proud of our dual role as "cultural guardians" and "information professionals," both existing under the heading of librarian. 